\title{
THE FIELD OF MYCOLOGY
}

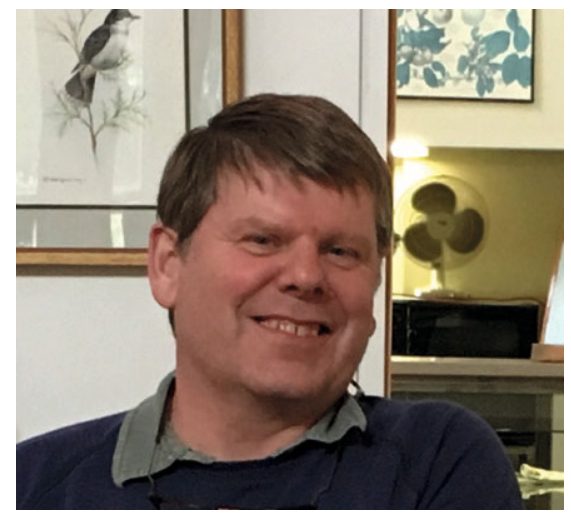

T ast summer in Athens, Georgia, USA, at the start of the annual conference of the Mycological Society of America, I spent Sunday afternoon with a few hundred colleagues walking through the forest for the annual collecting trip. We were joined by a group of high school biology teachers who were curious about fungi but unprepared for the behaviour of a foray of mycologists in the field. They stood off to the side, watching with evident concern as the mycologists plunged down slopes, crawled through wet patches of moss, and ripped rotting logs apart, peering at leaves through hand lenses, and tenderly wrapping fragile mushrooms in wax paper. Off-leash dogs nuzzled our boots, barked and dropped into the play position, certain that whatever it was we were doing, it was unusual, useless, and essential to warn the world about.

According to Wiki answers, there are 75 scientific fields (Qinones, s.d.), which seems like a gross underestimate to me. Fortunately, mycology is included. Each field includes a myriad of subdisciplines. At conferences, we tend to associate with a handful of people whose interests are precisely our own - other pursuits seems trivial and unimportant. This focus is necessary for us to progress with our research and these obsessions become core parts of our personalities. We form intense friendships with strangers while exchanging correspondence, specimens, cultures and DNA. As a teenager, I read Wampeters, Foma and Granfalloons (Vonnegut 1974), a collection of short stories with the theme of these strange words invented by its author. A 'foma' is a harmless untruth; a 'granfalloon' is a proud and meaningless association of people. With these two words, I was perfectly set up for a career in academia. This granfalloonery, it can be rather nice. I will always remember the $4^{\text {th }}$ International
Mycological Congress in Regensburg, Germany, held in 1990, the year after the Berlin Wall started to come down. A tidal wave of Eastern Europeans stepped off rusty trains and buses, unregistered for the IMC, many with little money and no place to sleep, anxious to make first contact with their western counterparts. It was an electric meeting as colleagues unexpectedly met their heroes and their enemies, and hundreds of people they had never heard of, for the first time. They walked in the woods together, swam in the Danube, and passionately presented their posters.

The first time I realized just how bizarre biologists appear when they are in field mode was when a friend-of-a-friend naturalist visited who was interested in snakes and ants. He hung a glass jar around his neck with two flexible tubes coming out of the stopper, a device I now know to be called an aspirator jar or a 'pooter'. He held one of the tubes over the scurrying ants, the other tube in his mouth, and sucked the ants through the tubing into the jar. His confidence that the bugs would end up in the jar and not in his mouth was admirable. His request to keep his colonies of living ants in our refrigerator beside our food tested our resolve to be generous hosts. Fortunately, he was unsuccessful in his mission to find snakes.

First excursions into the field are always mysterious. What do you do? What should you look for? You must learn to see with new eyes, but when you learn this, you see a new world. The invisible becomes visible, and we have a clearer picture of our place among other living beings. Like most of us, my first exposure to field mycology was a mushroom walk during an introductory course. The professor, Bryce Kendrick, had three dynamic graduate students with fanatical, sparkling eyes. We drove to the Laurel Creek conservation area of Waterloo, wandering slowly up the hill into the forest at an unbelievably slow pace, stopping every three $\mathrm{cm}$ to examine some odd growth on the ground. The grad students told us about their research, showing us the aeroaquatic, arbuscular, and endophytic fungi they were studying, picking them out of the forest like treasures in a candy store. The unknown was everywhere, in open sight once you knew what to look for. Every week, my MSc supervisor dragged us through the rain forests that surround the University of British Columbia. He lived for the days when trans-Pacific winds battered the coast and ripped branches off the old growth trees. He scurried around with a green army surplus satchel that we called the "Bandoni bag", slicing slimy or gelatinous growths from the bark of the fallen branches with his pocket knife.

It is always instructive to collect with different kinds of mycologists to see what they do, how they have trained their own eyes to perceive the microbial world. The stereotypes of mushroomers with wicker baskets and micro-mycologists crouching in one spot for hours with a magnifying glass, apparently not moving, are both true. But I also saw Bob Lichtwardt lead his students into the bayou after a Deep Hypha meeting in Baton Rouge, dressed in hip-waders and wet suits, with dip nets to catch the aquatic insects that harbored trichomycetes, after first checking the area for alligators. The reknowned myxomycetologist Harold Keller had his students use climbing gear to repel into trees to collect their specimens in masses of organic debris tens of metres above the forest floor. Indoor mycologists enter buildings with sellotape, swabs, and vacuum-driven air samplers. Soil mycologists have their teaspoons, shovels, sieves, tubes and bags. When I was in the final stages of finishing the Genera of Hyphomycetes in 2011, I took a weekend workshop in lichen identification at a local university. Irwin Brodo, known to all as Ernie and the lead author of the stunning Lichens of North America (Brodo et al. 2001), was our teacher. The campus was nearly empty on the Saturday afternoon as we trailed Ernie like a raft of ducklings following their mother. Fifteen of us huddled around a single tree examining the lichens on the bark with our hand lenses (Fig. 1C). I like this kind of collecting; you can stand up straight, you don't need to bend over or get dirty. Three non-mycologists walked by, two of them staring at us with suspicion. The third one said, "Don't worry, I think it's just a bunch of lichenologists."

Not all field stories are happy. Trips into the wilderness, beyond the reach of cell phones and hospitals, sometimes encounter bee swarms and biting snakes, or even suffer accidental super-gluing of a finger to the back of an crocodile, as depicted in cartoon 

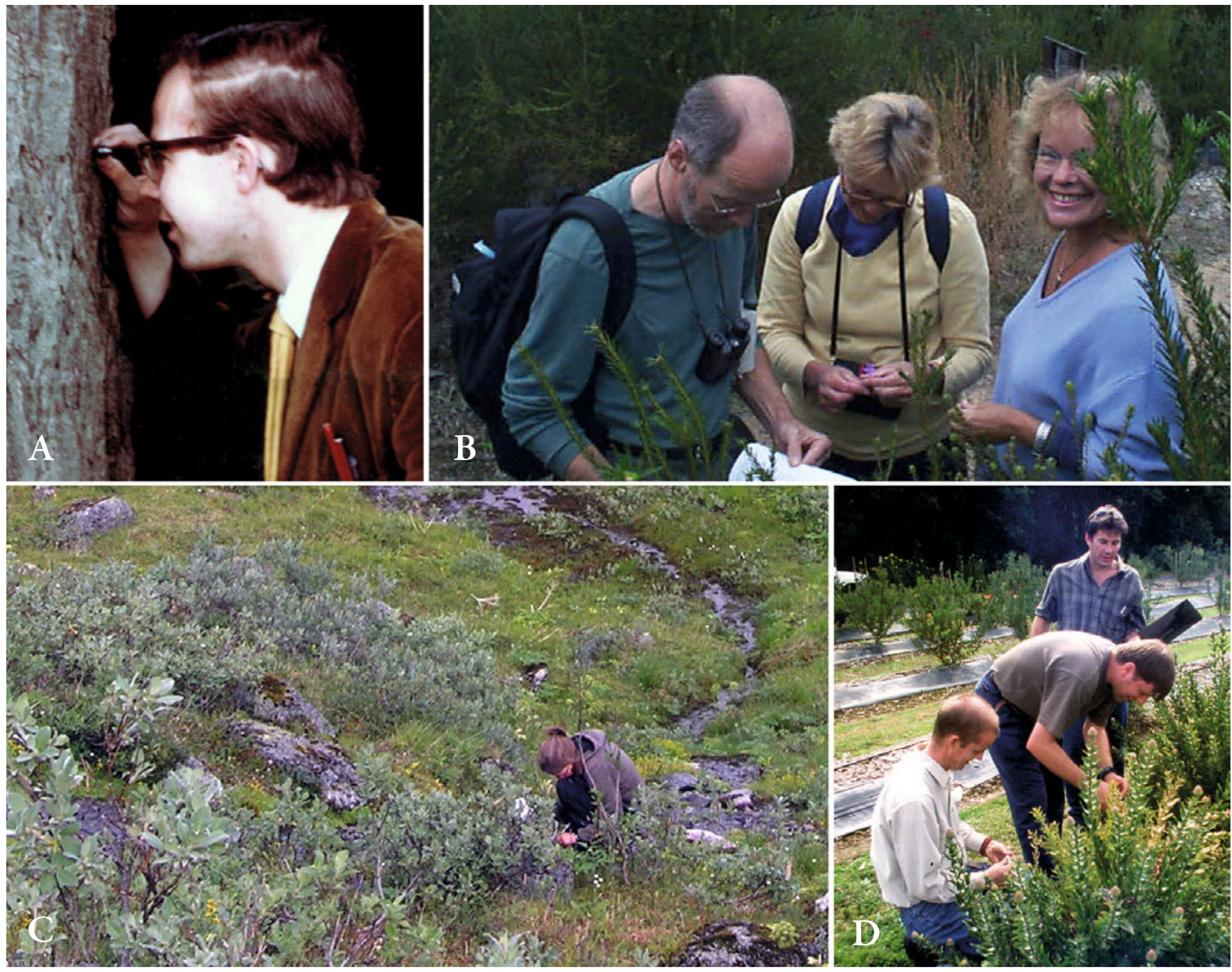

Mycologists in the field. A. David Hawksworth in the classic lichenologist pose, ca. 1970 (photographer unknown). B. John Taylor, Ellen Hoekstra, and Lene Lange during "Pitt's Personal Tour" of Sydney, Australia, 2001 (photograper unknown). C. Karen Hansen (photograph: Ibai Ibarguren). D. (right to left). Brett Summerell, Keith Seifert, and Pedro Crous in Australia in 1999.

form in Fieldwork Fail (Jourdain 2017). One famous story involves the Yankee geologist Elisha Mitchell, who fell to his death in 1857 in a waterfall at Yeate's Knob in North Carolina, USA. Decades later, the mycologist Kenneth B. Raper retraced his hero's steps and collected a soil sample that yielded the famous NC-4 strain of Dictyostelium discoideum, which became a standard model organism for cell and developmental biology. And then there are the near misses. A very tall colleague of mine slept through the night with his feet sticking out of the tent, his hiking boots left outside a short distance away. In the morning, his hiking boots were missing, and were discovered on the edge of the camp, chewed to bits by a tiger.

Through the years, I've had the opportunity to collect with many colleagues on many continents. Field work brings some sanity to work and conference travel and builds friendships. No matter what your status or predilections in the lab, the collection of a surprising or longsought fungus brings instant prestige. The distinction between students and professors evaporates when a discovery is made. Fungi are living beings and partners in our biological world. To truly understand them, to exploit them for our own purposes or protect ourselves from their unwanted interventions, we need to study them as they are, in the places where they struggle and the creativity of evolution allows them to thrive. Really, there is no distinction between field and lab mycologists. As I was working on this essay, I received photographs of many esteemed molecular and cell biologists exploring the natural world alongside their ecologist and taxonomist colleagues. I did not need these photographs as proof, actually, because I have wandered alongside mycologists of all persuasions throughout my career. We need to use all our creativity to succeed in developing anything that warrants the name 'all taxon biological inventory'. See the macrofungi yes, collect the sporophores and sporulating masses yes, but so many other strategies are needed to come close to gathering or observing everything. Every collecting method and every detection method has biases to be understood and overcome and every kind of observation is valuable in the quest for understanding.

It has been my privilege to serve as the President of the IMA for the past four years. I would like to thank the Officers and all members of the Executive Committee for their service to the Association; a bright future for international mycology is assured by their efforts. I am especially grateful to Secretary-General Pedro Crous (Fig. 1D) and Treasurer Karen Hansen (Fig. 1C) for their support during my tenure, and to 
Past-President John Taylor (Fig. 1B) and Honorary President and Editor-in-Chief of IMA Fungus David Hawksworth (Fig. 1A) for their wise counsel.

Brodo IM, Sharnoff SD, Sharnoff S (2001) Lichens of North America. New Haven, CT: Yale University Press.

Jourdain J (2017) Fieldwork Fail: the messy side of science. Makisapa. http://fieldworkfail.com/
Quinones J (undated) How many fields are there in Science? http://wiki.answers.com/Q/How_ many_fields_are_there_in_Science\#page23

Vonnegut K (1974) Wampeters, Foma and Grandfalloons. London: Dell Publishing.

Keith A. Seifert

President, IMA

(keith.seifert@agr.gc.ca) 